\title{
Sistem Informasi Penyewaan Kendaraan Bermotor Customer to Customer (C2C)
}

\author{
I Putu Sugi Almantara, A. A. K. Agung Cahyawan Wiranatha., Kadek Suar Wibawa \\ Program Studi Teknologi Informasi Universitas Udayana \\ Bukit Jimbaran, Bali, Indonesia, telp. (0361) 701806 \\ e-mail: sugi.almantara@yahoo.co.id, agung.cahyawan@unud.ac.id, suar wibawa@yahoo.com
}

\begin{abstract}
Abstrak
Penyewaan kendaraan bermotor dalam menunjang kebutuhan wisatawan yang ada di Bali untuk mengunjungi destinasi wisata sangat diperlukan, dikarenakan wisatawan memilih kendaraan sewaan dibanding sarana transportasi lainnya. Pemilik kendaraan umumnya menunggu pelanggan yang datang mencari kendaraan yang ingin disewa, sehingga menyebabkan bisnis sewa menyewa menjadi kurang berkembang dan tidak efisien bagi penyewa kendaraan. Teknologi informasi yang memiliki kelebihan terkait pemasaran dan pengelolaan data dapat dimanfaatkan melalui perangkat mobile untuk menunjang proses bisnis sewa menyewa kendaraan. Kelebihan teknologi informasi menjadi dasar pengembangan Sistem Informasi Penyewaan Kendaraan Bermotor Customer to Customer (C2C) berbasis mobile yaitu SIRENT. Aplikasi SIRENT bertujuan untuk meningkatkan kualitas bisnis bagi pemilik kendaraan dalam memasarkan kendaraan menggunakan metode Customer to Customer. Fitur-fitur yang dirancang pada aplikasi antara lain, manajemen data kendaraan, proses pembukuan/booking dan pencarian kendaraan. Hasil wawancara dengan beberapa pengguna dan pemilik rental kendaraan mengenai aplikasi SIRENT yaitu membantu pemasaran penyewaan kendaraan menggunakan model e-commerce jenis customer to customer, memudahkan proses pemesanan karena dapat dilakukan kapan saja dan dimana saja melalui perangkat mobile Android yang terhubung jaringan internet, dan memudahkan pengguna mencari kendaraan berdasarkan nama kendaraan, jenis kendaraan atau jarak tempat usaha penyewaan kendaraan terdekat serta memudahkan pengguna yang ingin melakukan pemesanan kendaraan dengan fitur booking pada SIRENT.
\end{abstract}

Kata kunci: Wisatawan, Transportasi, Sistem Informasi, Customer to Customer

Rental of vehicles are important in supporting the tourists needed in Bali, because many tourists prefer a rental vehicle than the other transportations. The vehicle's owner usually waits for customers who come and looking for a vehicle that they want to rent, thus it causing the rental of vehicles business being less developed and not efficient for tenants of the vehicle. The advantages of technology for marketing and managing data could be utilized for developing a mobile-based system of vehicles rental. The advantages of information technology became the basis for the development of mobile-based systems of vehicle rental customer to customer with the name SIRENT. The SIRENT application aimed to improve the quality of business for vehicle owners in marketing their vehicles by using the Customer to Customer (C2C) method. The features which available in this mobile application were: manage vehicle information, booking service and find a vehicle. Based on the interview process with some user and vehicle's owner, SIRENT application was able to helped the marketing process of vehicles by using ecommerce model customer to customer, facilitated the transaction process because customer could rent vehicles anytime and anywhere with Android mobile devices that connected to the internet, allowed user to search for the desired vehicle based on the name, type, or distance of the nearest rental of vehicle business, and facilitated user who want to rented vehicle with booking feature on SIRENT.

Keywords: Tourist, Transportation, Information System, Customer to Customer

\section{Pendahuluan}

Sistem Informasi Penyewaan Kendaraan Bermotor Customer to Customer (C2C)

(I Putu Sugi Almantara) 
Bali merupakan salah satu daerah tujuan destinasi wisata yang populer. Bali menjadi primadona di kalangan wisatawan karena memiliki kesenian dan budaya yang unik dan menarik, juga keindahan alamnya indah [1]. Destinasi wisata di pulau Bali berada tersebar hampir diseluruh pelosok daerah Bali. Wisatawan yang datang ke Bali tidak hanya berasal dari dalam negeri terdapat juga wisatawan yang datang dari mancanegara. Data Dinas Pariwisata Provinsi Bali menunjukkan bahwa pada tahun 2015 wisatawan yang datang ke Bali umumnya memilih kendaraan sewaan sebagai sarana transportasi sebesar $39,2 \%$, disusul mobil pribadi $32.9 \%$, sepeda motor $18,1 \%$ dan kendaraan umum 9,8\% [2].Beberapa masyarakat yang khususnya tinggal pada daerah pariwisata menyewakan kendaraannya sebagai peluang yang dapat dijadikan suatu nilai tambah untuk kendaraan pribadi yang tidak terpakai.

Usaha sewa menyewa kendaraan kini sudah mulai banyak di daerah yang memang menjadi tujuan wisatawan karena dibutuhkan oleh wisatawan baik itu wisatawan lokal maupun asing untuk membantu perjalanan selama berlibur di Bali. Wisatawan atau orang yang hendak menyewa suatu kendaraan baik seperti mobil atau motor umumnya mengunjungi tempat usaha penyewaan kendaraan untuk mendapatkan informasi seperti administrasi selama penyewaan kendaraan, kendaraan yang ingin disewa, maupun harga sewa kendaraan. Masalah yang dapat timbul terkait sistem sewa yang ada diantaranya pencarian kendaraan untuk disewa memerlukan waktu cukup lama, dan mendapatkan informasi harga kendaraan yang tidak konsisten. Teknologi dapat dimanfaatkan dan berperan penting untuk memenuhi tujuan bisnis ataupun digunakan untuk membagikan informasi yang penting [3]. Teknologi informasi sebagai acuan dalam perkembangan jaman mengakibatkan kebutuhan informasi meningkat tajam [4]. Internet merupakan salah satu faktor pendukung dari teknologi dalam mengembangkan bisnis dan membagikan informasi untuk masyarakat yang turut serta menggunakan internet. Bisnis online memiliki prospek yang cukup besar dan hampir semua orang menginginkan kepraktisan dan kemudahan dalam hal tersebut [5]. Internet juga semakin dekat dengan kehidupan bahkan kebanyakan orang sangat bergantung pada internet untuk melakukan aktivitas sehari-hari seperti menyelesaikan tugas kantor atau kuliah, berbelanja online, dan jejaring sosial [6].

Permasalahan terkait sewa menyewa kendaraan di Bali dan pentingnya pemanfaatan teknologi termasuk internet melatarbelakangi perancangan Sistem Informasi Penyewaan Kendaraan Bermotor Customer to Customer (C2C) atau aplikasi Sistem Informasi Rental (SIRENT). SIRENT merupakan sebuah aplikasi yang dirancang bertujuan untuk memasarkan kendaraan yang dapat disewa, serta membantu wisatawan mencari kendaraan berdasarkan nama dan jenis kendaraan atau pencarian berdasarkan jarak terdekat usaha penyewaan kendaraan bermotor. SIRENT dilengkapi dengan fitur pemesanan kendaraan, pencarian kendaraan, bantuan penyewa dan pengingat durasi masa sewa kendaraan. SIRENT dikembangkan dalam sebuah perangkat mobile berbasis Android.

\section{Metodologi Penelitian}

Metodologi penelitian Sistem Informasi Penyewaan Kendaraan Bermotor Customer to Customer yaitu pendefinisian masalah dan batasan masalah dari sistem yang dibuat, merancang model sistem dalam bentuk diagram konteks, proses bisnis sistem dan diagram alir yang digunakan sebagai landasan perancangan dan pengembangan sistem, pengujian sistem yang telah dibuat dan telah dipasang pada perangkat mobile kemudian dilakukan analisis hasil pengujian sistem dan pengambilan kesimpulan. Gambar 1 menunjukkan alur penelitian dari Sistem Informasi Penyewaan Kendaraan Bermotor Customer to Customer (C2C). Alur penelitian dilakukan mulai dari tahap pendefinisian masalah dari penelitian yang dilakukan sampai mendapatkan kesimpulan dari hasil penelitian yang dilakukan. 


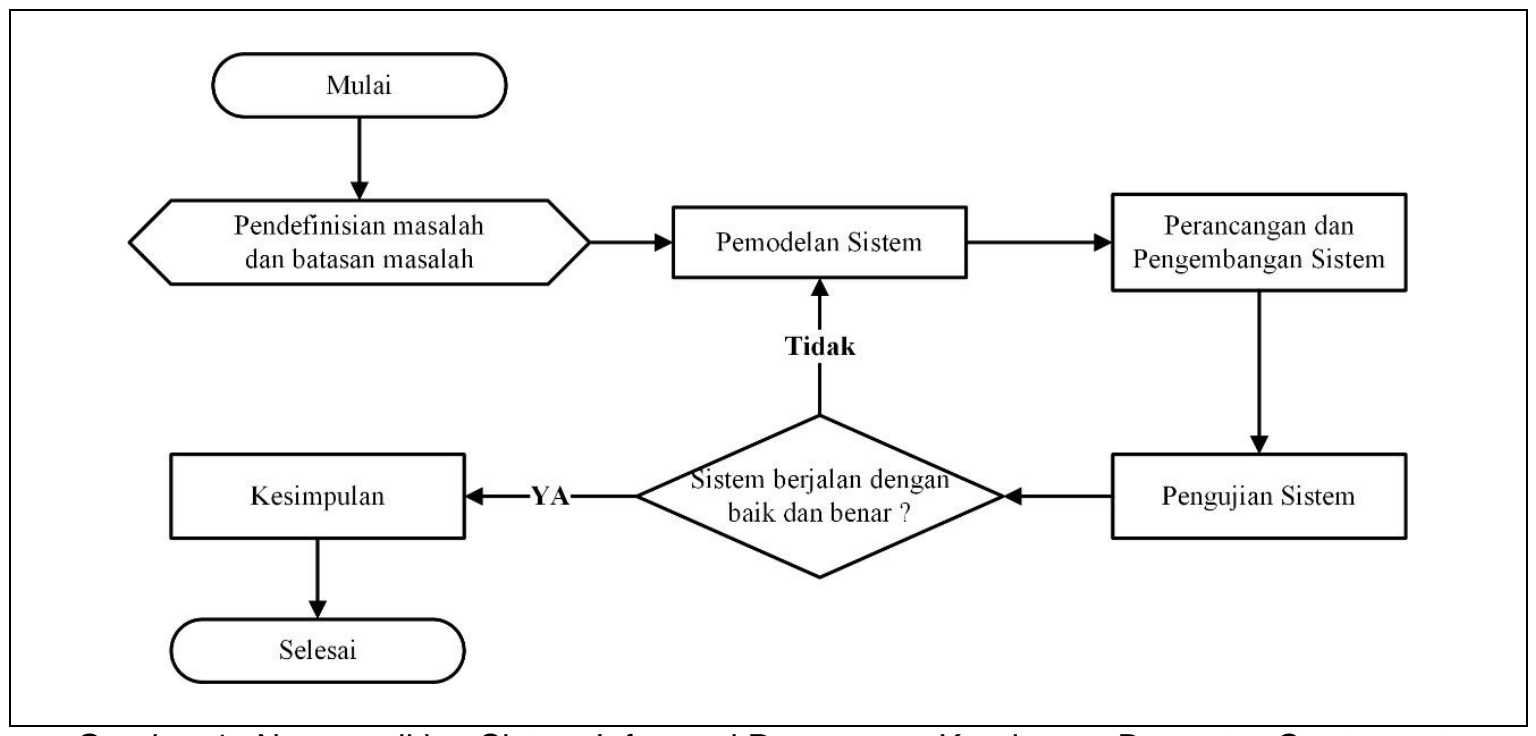

Gambar 1. Alur penelitian Sistem Informasi Penyewaan Kendaraan Bermotor Customer to Customer (C2C)

\subsection{Gambaran Umum Sistem}

Sistem Informasi Penyewaan Kendaraan Bermotor Customer to Customer (C2C) merupakan sistem informasi yang dibuat untuk penyewaan kendaraan bermotor secara online. Sistem Informasi Penyewaan Kendaraan Bermotor Customer to Customer (C2C) yakni SIRENT menggunakan perangkat mobile berbasis Android sebagai alat untuk melakukan transaksi sewa menyewa kendaraan. Hak akses pada Aplikasi SIRENT dibagi menjadi 2 yaitu pengguna yang dapat melakukan pemesanan kendaraan, mencari kendaraan berdasarkan nama, jenis atau lokasi tempat penyewaan kendaraan terdekat dan pemilik kendaraan yang dapat memasukkan data kendaraan, mengubah atau menghapus data kendaraan, melakukan konfirmasi pemesanan penyewaan kendaraan dan pembatalan penyewaan kendaraan.

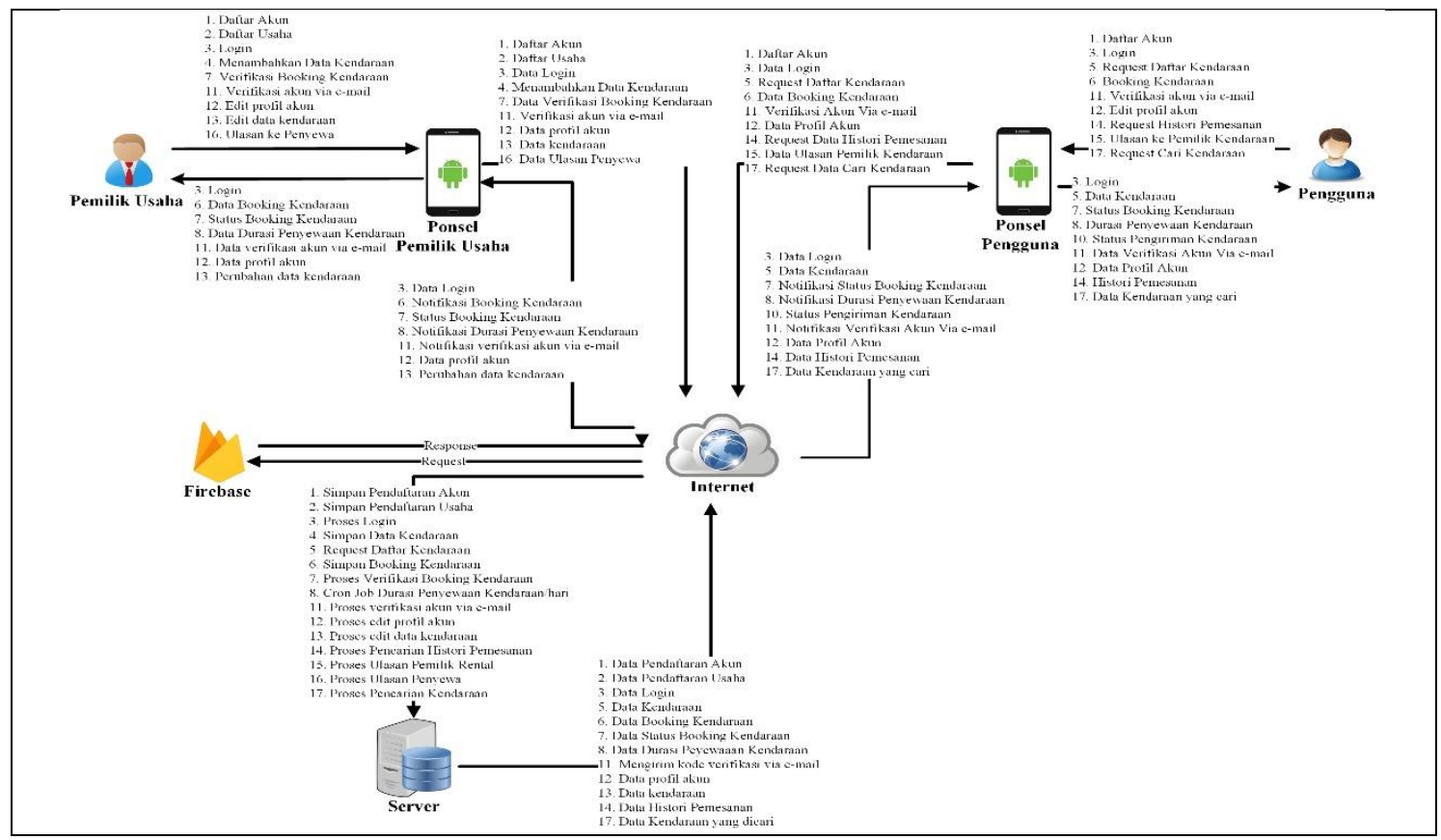

Gambar 2. Gambaran umum Sistem Informasi Penyewaan Kendaraan Bermotor Customer to Customer (C2C) 
Gambar 2 merupakan gambaran umum Sistem Informasi Penyewaan Kendaraan Bermotor Customer to Customer (C2C). Aplikasi SIRENT menggunakan Firebase API untuk mendukung fitur notifikasi pada Aplikasi SIRENT. Pengguna yang telah melakukan proses pemesanan kendaraan selanjutnya menunggu konfirmasi pemesanan oleh pemilik kendaraan. Pemilik kendaraan menerima notifikasi pemesanan kendaraan secara real time dan melakukan konfirmasi pemesanan, setelah pemilik kendaraan melakukan konfirmasi kemudian notifikasi konfirmasi pemesanan diterima oleh pengguna untuk mengetahui status pemesanan penyewaan kendaraan. Pengguna dan pemilik kendaraan juga menerima notifikasi sisa masa durasi sewa kendaraan. Pengguna dapat menggunakan fitur bantuan yang disediakan pada Aplikasi SIRENT untuk mengatasi masalah kendaraan yang disewa. Fitur bantuan langsung ditujukan kepada pemilik kendaraan yang bersangkutan.

\section{Kajian Pustaka}

Kajian pustaka berisi teori mengenai teknologi yang merupakan teori pendukung yang menjadi landasan teori untuk pemecahan masalah dari penelitian Sistem Informasi Penyewaan Kendaraan Bermotor Customer to Customer (C2C).

\subsection{E-Commerce}

E-commerce merupakan sebuah transaksi jual beli yang terjadi melalui sistem elektronik seperti internet atau jaringan komputer lainnya. E-commerce melibatkan pertukaran data elektronik dan sistem pengumpulan data otomatis [7].

\subsection{Customer to Customer (C2C)}

Customer to Customer merupakan interaksi yang dilakukan oleh satu pelanggan kepada pelanggan lain dengan cara yang berpotensi mengubah perilaku pembelian atau berinteraksi dengan orang lain [8]. Contoh portal e-commerce yang menerapkan konsep C2C adalah e-bay, tokopedia dan olx. Pengelolaan hubungan antar pelanggan/Customer Relationship Management (CRM) merupakan strategi yang dibangun untuk menguatkan hubungan pelanggan. CRM dilihat tidak hanya dari barang atau jasa, tetapi dari filosofi bisnis yang bertujuan untuk memaksimalkan nilai pelanggan jangka panjang [9].

\subsection{Firebase}

Firebase merupakan teknologi yang memungkinkan seorang membuat aplikasi web tanpa pemrograman server-side sehingga pengembangannya menjadi lebih mudah dan cepat. Firebase merupakan platform pengembangan aplikasi yang menyediakan beragam alat dan infrastruktur terukur untuk membangun aplikasi berkualitas tinggi. Firebase Cloud Messaging (FCM) merupakan pengiriman pesan lintas platform berupa pesan notifikasi atau pesan data [10]. Firebase merupakan teknologi yang dikembangkan oleh Google, sama halnya dengan Google Map API yang merupakan peta dunia digital yang dapat diakses secara gratis. Google Map API sangat berguna dalam pengembangan aplikasi map untuk membantu pencarian tempat bisnis secara interaktif [11].

\section{Hasil dan Pembahasan}

Uji coba sistem informasi penyewaan kendaran bermotor menggunakan spesifikasi perangkat mobile yang ditunjukkan Tabel 1 . Sistem operasi yang dapat menjalankan aplikasi adalah perangkat mobile Android dengan operating system minimal Lollipop. 
Tabel 1. Spesifikasi perangkat pengujian

\begin{tabular}{ll}
\hline Jenis Hardware & Spesifikasi \\
\hline & Sony Xperia Z1 \\
& Processor Quad Core \\
Mobile Phone I & Layar 5.0 inch $1080 \times 1920$ pixels \\
(Pelanggan) & RAM 2GB \\
& Sistem operasi Android Lollipop 5.1 \\
& Sensor Kompas \\
\hline & Sony Xperia Z1 \\
& Processor Quad Core \\
& Layar 5.0 inch 1080 x 1920 pixels \\
Mobile Phone II & RAM 2GB \\
(Pemilik rental) & Sistem operasi Android Lollipop 5.1 \\
& Sensor Kompas \\
\hline
\end{tabular}

\subsection{Tampilan Aplikasi SIRENT}

Tampilan Aplikasi SIRENT dijelaskan pada subbab pembahasan dan uji coba sistem. Uji coba sistem dijelaskan mulai dari tahap pendaftaran hingga pemesanan penyewaan kendaraan.

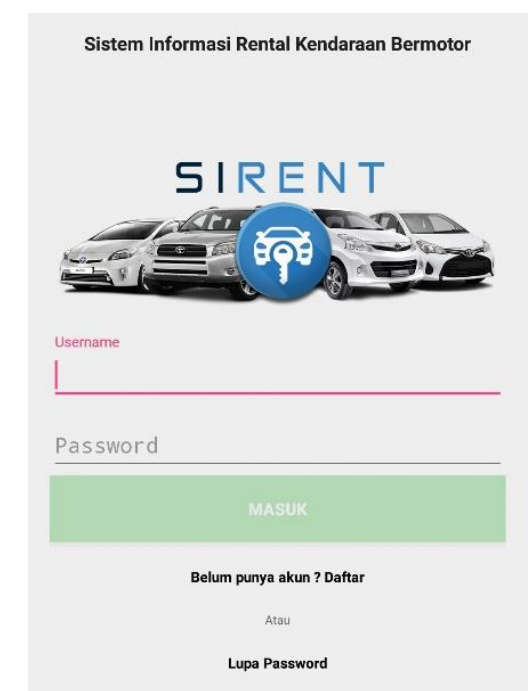

Gambar 2. Tampilan login SIRENT

Gambar 2 merupakan tampilan login pada SIRENT. Pengguna dapat masuk ke dalam sistem dengan memasukkan username dan password, melakukan pendaftaran akun dengan memilih menu daftar dan melakukan proses lupa password dengan memilih menu lupa password. Pengguna yang ingin melakukan pemesanan kendaraan wajib memiliki akun yang telah terdaftar dan diverifikasi melalui email yang telah didaftarkan pada proses pendaftaran akun. 


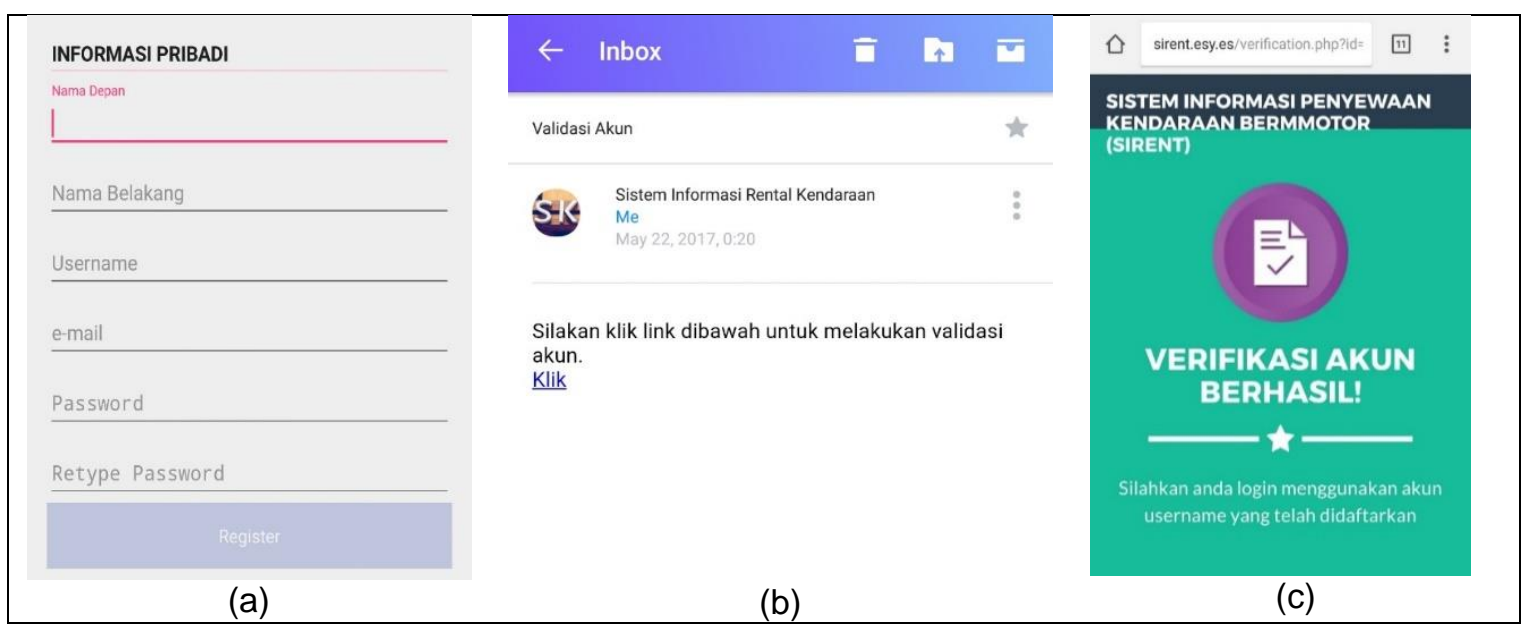

Gambar 3. (a) Tampilan pendaftaran user, (b) Tampilan verifikasi via email, (c) Tampilan verifikasi via web

Gambar 3(a) merupakan tampilan pendaftaran pengguna dengan memasukkan informasi berupa nama, username yang digunakan untuk masuk ke dalam sistem, email yang digunakan untuk melakukan verifikasi akun dan password. Gambar 3(b) menunjukkan proses verifikasi via email yang dilakukan oleh pengguna setelah melakukan pendaftaran pada sistem. Gambar 3(c) menunjukkan proses verifikasi yang berhasil via web dan akun yang telah terdaftar dapat digunakan untuk masuk ke dalam sistem.

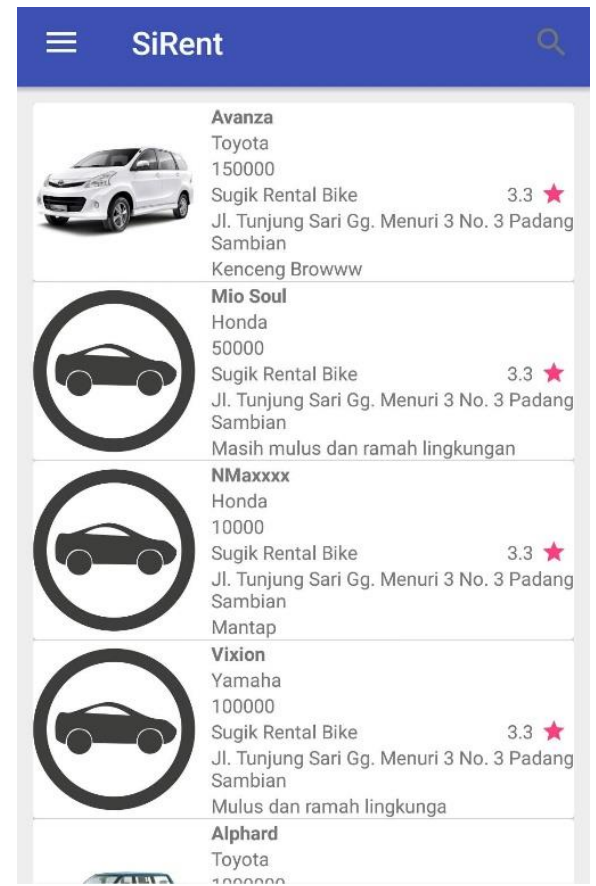

Gambar 4. Tampilan daftar kendaraan pada SIRENT

Gambar 4 merupakan daftar kendaraan yang sudah didaftarkan oleh pemilik kendaraan pada Aplikasi SIRENT. Informasi kendaraan yang ditampilkan pada aplikasi berupa nama kendaraan, harga sewa per hari, lokasi tempat penyewaan kendaraan dan deskripsi kendaraan. 


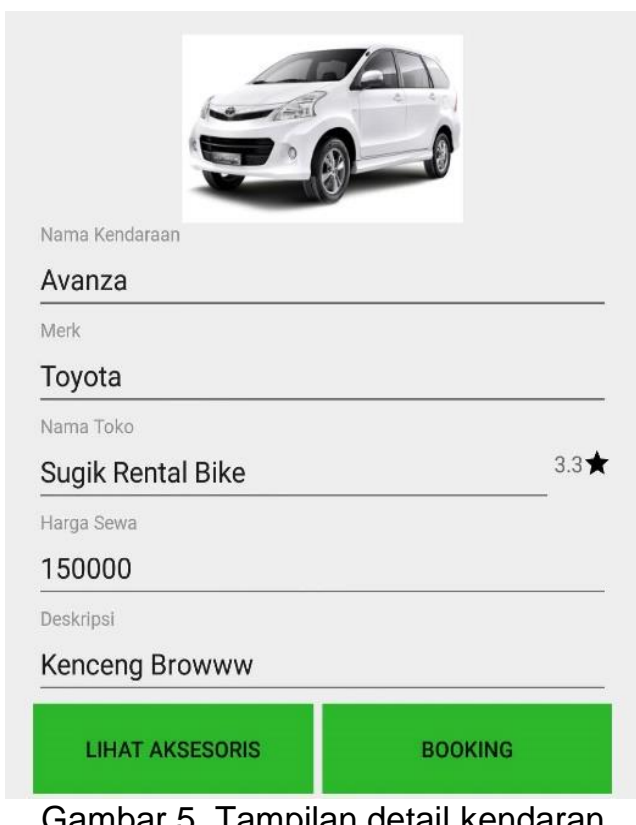

Gambar 5 merupakan tampilan detail dari kendaraan yang dipilih oleh pengguna untuk selanjutnya disewa. Pengguna dapat melihat aksesoris tambahan yang ada pada kendaraan yang muncul berupa tampilan dialog dan untuk proses pemesanan dapat dilakukan dengan memilih menu booking pada tampilan detail kendaraan.

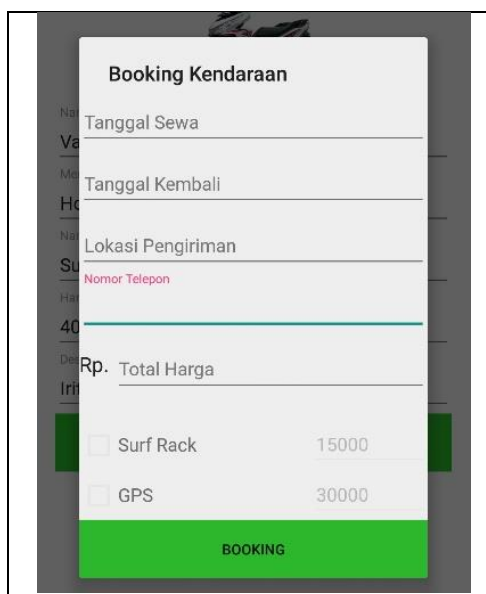

(a)

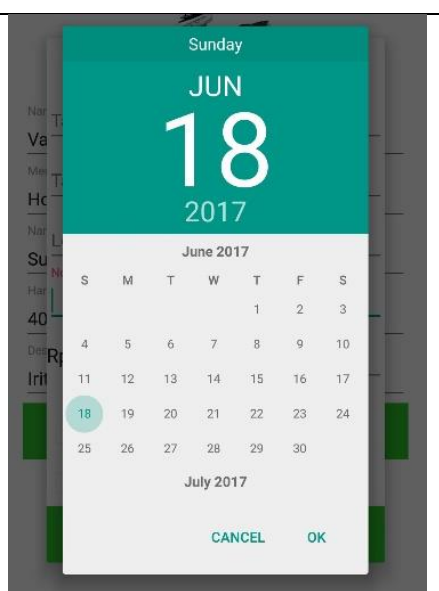

(b)

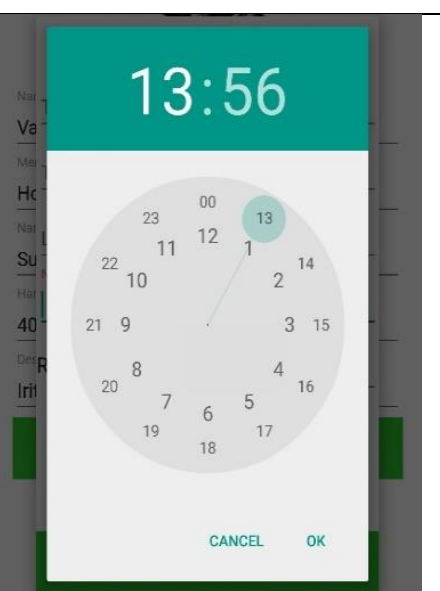

(c)

Gambar 6. (a) Tampilan isian formulir pemesanan, (b) tampilan pilihan tanggal sewa dan kembali, (c) tampilan pilihan waktu pengiriman kendaraan

Gambar 6 merupakan proses pemesanan suatu kendaraan yang dilakukan oleh pengguna. Pemesanan dimulai dengan mengisi formulir yang terdapat pada Gambar 6(a) yang berisikan alamat pengiriman kendaraan dan nomor telepon yang dapat dihubungi. Gambar 6(b) merupakan tampilan pemilihan tanggal sewa dan tanggal kembali, Gambar 6(c) merupakan tampilan pemilihan waktu pengiriman kendaraan. 


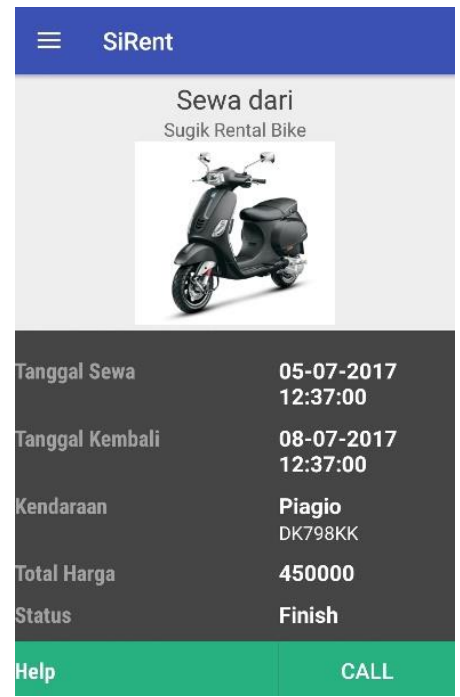

Gambar 7. Tampilan status pemesanan

Gambar 7 merupakan tampilan status pemesanan milik pengguna. Status pemesanan dapat dilihat setelah pengguna berhasil melakukan proses pemesanan kendaraan. Informasi yang terlihat pada tampilan status pemesanan kendaraan berupa tanggal sewa dan tanggal kembali, kendaraan yang disewa, total harga, dan status pemesanan kendaraan.

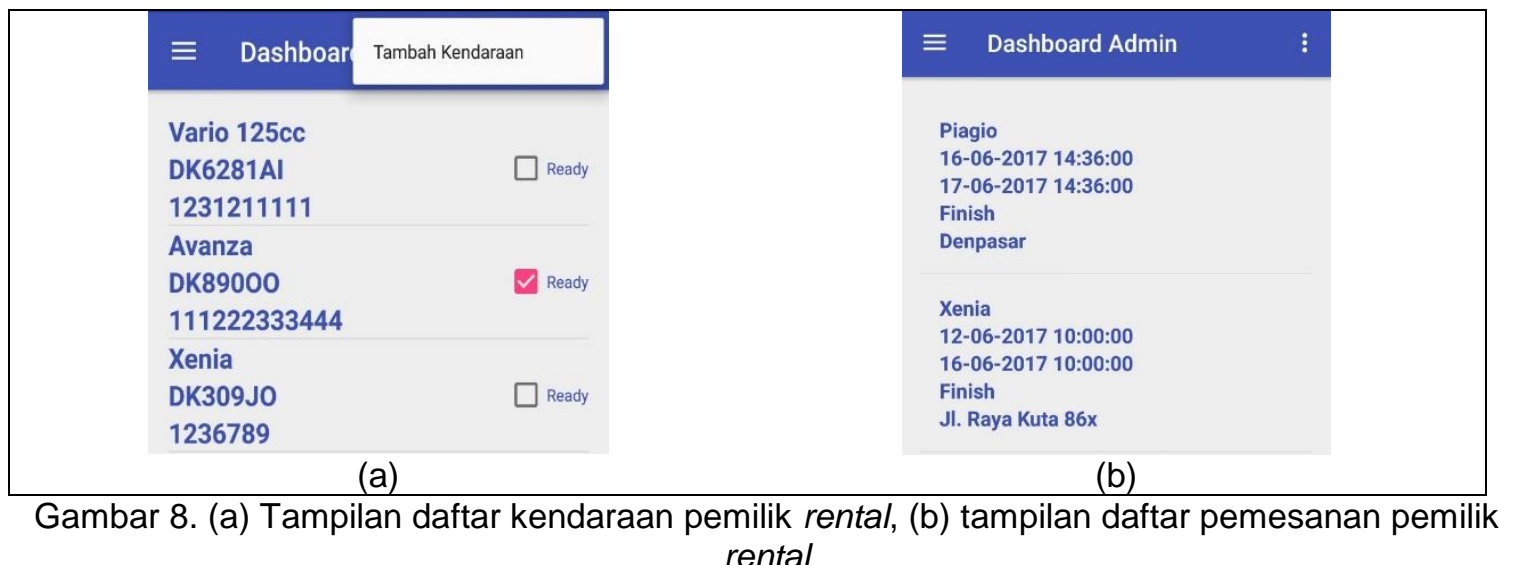

Gambar 8(a) merupakan daftar kendaraan yang dimiliki oleh pemilik rental pada SIRENT. Gambar 8(b) merupakan daftar pemesanan kendaraan yang masuk pada pemilik rental. Gambar 9 merupakan notifikasi pemesanan kendaraan yang masuk pada perangkat mobile pemilik rental. Notifikasi muncul secara real time setelah pengguna telah menyelesaikan proses pemesanan kendaraan pada SIRENT.

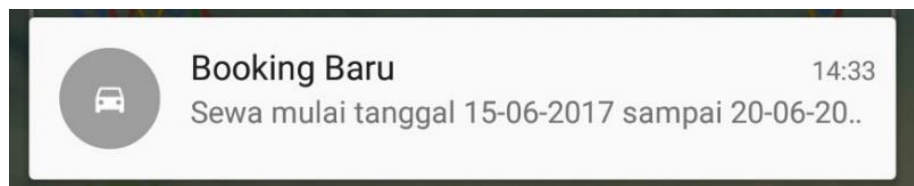

Gambar 9. Notifikasi pemesanan kendaraan

\subsection{Evaluasi Pengguna}

Implementasi Aplikasi SIRENT berdasarkan evaluasi terhadap pengguna memiliki manfaat yang dapat membantu mencari kendaraan yang diinginkan berdasarkan jenis kendaraan, nama kendaraan atau lokasi terdekat dari pengguna. Manfaat Aplikasi SIRENT terhadap pemilik rental yaitu mendukung pemasaran kendaraan yang disewa menggunakan model e-commerce customer to customer, membantu memudahkan proses transaksi 
pembukuan kendaraan yang dapat dilakukan kapan saja dan dimana saja melalui perangkat mobile Android yang telah terhubung dengan jaringan internet. Evaluasi pengguna terhadap Aplikasi SIRENT didapatkan dengan wawancara pengguna dan dengan pemilik rental kendaraan.

\section{Kesimpulan}

Sistem Informasi Penyewaan Kendaraan Bermotor Customer to Customer (C2C) diaplikasikan dalam bentuk sebuah Aplikasi Mobile dengan nama SIRENT. Jenis hak akses pengguna/user pada sistem dibagi menjadi 2 jenis, yaitu pemilik rental dan penyewa/pengguna. Sistem dirancang dan dibangun khusus untuk perangkat mobile dengan platform Android yang dapat digunakan oleh pemilik rental dan penyewa/pengguna. Aplikasi SIRENT yang dihasilkan telah mampu melakukan manajemen data seperti memasukkan data kendaraan, mengubah data kendaraan (update data), proses transaksi, dan proses pembatalan transaksi yang terkait dengan kegiatan transaksi sewa menyewa kendaraan bermotor baik bagi pemilik rental dan penyewa/pengguna. Hasil wawancara dengan beberapa pengguna dan pemilik rental kendaraan mengenai Aplikasi SIRENT yaitu membantu pemasaran kendaraan untuk disewakan menggunakan model e-commerce jenis customer to customer, memudahkan proses penyewaan kendaraan karena dapat dilakukan kapan saja dan dimana saja dengan perangkat mobile Android yang telah terhubung dengan jaringan internet, dan memudahkan pengguna yang ingin melakukan pemesanan kendaraan dengan fitur booking serta memudahkan pengguna mencari kendaraan berdasarkan nama kendaraan, jenis kendaraan atau jarak tempat usaha penyewaan kendaraan terdekat pada Aplikasi SIRENT.

\section{Daftar Pustaka}

[1] I. W. W. Gautama, I. K. G. Darma Putra and I. M. Sukarsa, "Aplikasi Pemetaan Objek Wisata Pantai Bali Selatan," Merpati, vol. 4, pp. 43-51, 2016.

[2] Statistik-Disparda Bali, Analisis Pasar Wisatawan Nusantara 2015, Denpasar: Dinas Pariwisata Provinsi Bali, 2017.

[3] P. A. Jaya Kusuma, I. K. A. Purnawan and N. M. I. Mandenni, "Aplikasi Sistem Informasi Hotel Berbasis Android," Merpati, vol. 3, pp. 16-22, 2015.

[4] I. B. P. Gamaswara, A. A. K. Oka Sudana and N. M. I. M. Mandenni, "Perancangan Sistem Informasi Manajemen Modul Layanan Pada Rumah Sakit," Lontar Komputer, vol. 6, pp. 163174, 2015.

[5] S. A. Pratiwi, I. M. Sukarsa and I. K. A. Purnawan, "Rancang Bangun Aplikasi Sistem Pemesanan Bunga Berbasis Android," Merpati, vol. 2, pp. 205-214, 2014.

[6] S. Y. Frediyatma, "Aplikasi Pemesanan Makanan Berbasis Cloud dengan Platform Android," Merpati, vol. 2, pp. 118-126, 2014.

[7] N. M. A. Lestari and M. Sudarma, "Perencanaan Search Engine E-commerce dengan Metode Latent Semantic Indexing Berbasis Multiplatform," Lontar Komputer, vol. 8, pp. 3140, 2017.

[8] Barak Libai, B. Ruth, S. B. Marrix , d. R. Ko, G. Oliver, R. Hans and S. Andrew T., "Customer-to-Customer Interactions: Broadening the Scope of Word of Mouth Research," Journal of Service Research, p. 267, 2010.

[9] I. K. G. Darma Putra, A. A. K. A. Cahyawan and D. Shavitri H., "Combination of Adaptive Resonance Theory 2 and RFM Model for Customer Segmentation In Retail Company," International Journal of Computer Applications, vol. 48 No. 2, pp. 18-23, 2012.

[10] A. Rahmi, I. N. Piarsa and P. W. Buana, "FinDoctor-Interactive Android Clinic Geographical Information System Using Firebase and Google Maps API," International Journal of New Technology and Research, vol. 3, no. 7, pp. 08-12, 2017.

[11] I. N. Piarsa, A. A. K. Oka Sudana and G. W. M. Gunadi, "Web-based GIS by using Spatial Decision Support System (SDSS) Concept for Searching Commercial Marketplace - using Google MAP API," International Journal of Computer Applications, vol. 50 No. 7, pp. 1-5, 2012. 